\title{
Perkembangan Penelitian Sejarah Akuntansi di Indonesia dalam Bingkai Perspektif NAH
} \section{The Development of Historical Accounting Research in Indonesia in a Perspective of NAH}

\author{
Ajeng Tita Nawangsari ${ }^{1 *}$, Nur Ravita Hanun ${ }^{2}$ \\ ${ }^{1}$ UIN Sunan Ampel, Surabaya, Indonesia, ${ }^{2}$ Universitas Muhammadiyah, Sidoarjo, Indonesia
}

This study aims to capture the development of new accounting history research in order to understand the extent to which accounting history has been carried out and the possible direction of research in the future. This study use literature review to collect the data. The result shows that the NAH research in Indonesia has been carried out such as accounting research during the colonial period, the early era of Indonesia's independence, the ancient java and Bali period. However, the opportunity to do the New accounting history research in Indonesia is still widely open considering that Indonesia is a country with many cultures and dynamics. Some opportunities in this field are accounting research in the west java kingdom, during IslamicKingdom and contemporary accounting research which can describe various current accounting dynamics that impact the development of accounting.

Keywords: Accounting History, New Accounting History, The Development of Accounting History Research

OPEN ACCESS

ISSN 2548-3501 (online)

Edited by:

Eny Maryanti

Reviewed by:

Sigit Hermawan

*Correspondence:

Ajeng Tita Nawangsari ajeng.tita@uinsby.ac.id

Received: 03 Maret 2020

Accepted: 10 Juni 2020

Published: 31 Juli 2020

Citation:

Nawangsari AT and Hanun NR (2020) Perkembangan Penelitian

Sejarah Akuntansi di Indonesia

dalam Bingkai Perspektif NAH.

Journal of accounting Science. 4:2.

doi: 10.21070/jas.v4i2.894
Penelitian ini bertujuan untuk menggambarkan perkembangan penelitian sejarah Akuntansi di Indonesia yang diteliti dengan menggunakan pendekatan New Accounting History (NAH). Hal ini dilakukan untuk dapat mendapatkan peta gambaran tentang sejauh mana penelitian sejarah akuntansi telah dilakukan dan kemungkinan arah penelitian di masa yang akan datang. Metode yang digunakan dalam penelitian ini adalah literature review. Hasil penelitian menunjukan bahwa penelitian sejarah akuntansi di Indonesia dengan menggunakan pendekatan NAH sudah mulai dilakukan seperti penelitian akuntansi pada masa kolonial belanda, era awal kemerdekaan di Indonesia, masa Jawa dan Bali kuno. Walaupun demikian, peluang penelitian sejarah Akuntansi di Indonesia masih terbuka mengingat Indonesia merupakan negara dengan banyak budaya dan dinamika. Beberapa peluang penelitian sejarah akuntansi yang masih bisa dilakukan adalah penelitian akuntansi pada masa kerajaan-kerajaan yang ada di Jawa Barat, kerajaan Islam dan penelitian sejarah akuntansi kontemporer yang dapat menggambarkan berbagai dinamika akuntansi masa kini yang mewarnai perkembangan Akuntansi.

Keywords: Sejarah Akuntansi, New Accounting History, Perkembangan Penelitian Sejarah Akuntansi 


\section{PENDAHULUAN}

Sejarah merupakan bagian dari kehidupan manusia yang tidak bisa dilepaskan. Dengan melihat sejarah kita bisa memahami masa sekarang dan masa depan dengan lebih baik lagi. Hal tersebut juga berlaku bagi akuntansi. Akuntansi yang ada saat ini bisa kita pahami melalui pembacaan sejarah akuntansi di masa yang lalu. Riset tentang sejarah akuntansi di Indonesia memang tidak seramai penelitian lain yang membahas tentang isu-isu kontemporer dalam akuntansi. Walaupun demikian, penelitian sejarah akuntansi mulai mengalami geliat perkembangan. Beberapa penelitian tentang sejarah akuntansi telah dilakukan. Jika menilik penelitian sejarah akuntansi di jurnal-jurnal internasional, kita akan menemukan bahwa ada dua sudut pandang dalam menelaah sejarah akuntansi di masa yang lalu. Dua pendekatan tersebut adalah pendekatan Tradisional Accounting History dan New Accounting History Stewart (1992). Pendekatan tradisional memandang bahwa akuntansi merupakan fenomena teknis yang independen atau berdiri sendiri dan terpisah dari lingkungan sosial yang dipraktikan sehingga sifatnya adalah historis Burchell et al. (1985) Ezzamel and Willmott (2004) Hoskin and Macve (1986) Miller and Leary (1987); Miller (1993). Sebaliknya, New Accounting History memandang bahwa akuntansi merupakan sebuah ilmu pengetahuan yang muncul, berkembang dan berubah seiring dengan dinamika lingkungan sosialnya Poster (1982). Dengan menempatkan Akuntansi pada posisi tersebut, artinya titik tolak dalam melakukan riset akuntansi tidak hanya terpaku pada pencarian asal-usul ilmu tersebut misalnya saja adalah tentang debet dan kredit tetapi juga penelitian sejarah harus mampu mendeskripsikan interaksi dua arah antara lingkungan tempat akuntansi dipraktikan dengan bentuk akuntansi yang ada pada masa tersebut. Interaksi dua arah yang dimaksud berhubungan dengan hubungan timbal balik antara akuntansi dengan lingkungannya sehingga bukan hanya bentuk praktik akuntansi yang dapat dipengaruhi oleh lingkungan sosialnya yang menjadi fokus penelitian sejarah akuntansi namun juga bagaimana akuntansi dapat mempengaruhi pembentukan bebagai aspek kehidupan masyarakat yang ada di dalamnya.

Ide-ide riset sejarah dengan pendekatan tersebut memang sudah sangat lama dikenal yaitu pada sekitar tahun 1980an. Ide tersebut muncul dari sebuah kritik tentang penelitianpenelitian akuntansi yang hanya berfokus pada penelusuran aspek teknikal saja dan cenderung menempatkan akuntansi sebagai ilmu yang steril sehingga akuntansi menjadi ahistoris dan kuno Stewart (1992). Di Idonesia dilakukan oleh Sukoharsono and Gaffikin (1993a) dengan judul the genesis of accounting in Indonesia. Pendekatan yang digunakan untuk membahas mengenai akuntansi di Indonesia era kolonialisme adalah pendekatan baru dalam pembacaan sejarah dengan menggunakan pendekatan power-knowledge oleh Michael faucoult. Sejak saat itu mulai banyak periset sejarah akuntansi yang kemudian meneliti sejarah akuntansi dengan menggunakan pendekatan New Accounting History. Setelahnya, banyak sekali penelitian di Indonesia yang membahas tentang sejarah akuntansi dengan menggunakan pendekatan serupa dengan penelitian Sukoharsono tersebut. Beberapa diantaranya adalah penelitian yang dilakukan oleh Budiasih and Sukoharsono (2012); Budiasih (2016); Lutfillah et al. (2016); Lutfillah (2014); Lutfillah and and (2013); Bastian (2014); Widhianningrum et al. (2019). Hal ini membuat penelitian sejarah akuntansi dengan perspektif NAH kemudian bisa diamati kinerjanya dan bisa diketahui pola perkembangannya. Sejalan dengan itu, penelitian ini bertujuan untuk dapat mengcapture perkembangan penelitian sejarah akuntansi di Indonesia dalam frame pendekatan "New Accounting History" tersebut. Hal ini dilakukan untuk dapat memberikan gambaran tentang sejauh mana penelitian sejarah akuntansi dengan perspektif NAH telah dilakukan sehingga pembaca terutama para penggiat sejarah akuntansi bisa melakukan pemetaan penelitian sejarah akuntansi untuk dapat menemukan pola dan kemungkinan penelitian sejarah akuntansi dimasa yang akan datang.

\section{METODE PENELITIAN}

Metode penelitian yang digunakan dalam penelitian ini adalah literature review atau telaah pustaka. Telaah pustaka yang berfokus pada penelitian-penelitian sejarah dengan pendekatan NAH ini digunakan untuk dapat melihat perkembangan penelitian sejarah akuntansi di Indonesia. Data yang digunakan dalam penelitian ini adalah seluruh penelitian sejarah yang ada di Indonesia yang terpublikasi dalam jurnal nasional terindeks SINTA ,internasional terindeks pada Web of Science dan Australian Business Dean Council, maupun yang terbit dalam prosiding terindeks Scopus. Jurnal-jurnal yang telah dikumpulkan tersebut kemudian dibuat ringkasan jurnal yang meliputi nama peneliti, judul atau tema penelitian, metode penelitian, fokus dan ringkasan hasil atau temuan. Ringkasan jurnal tersebut dijabarkan dalam bentuk paragraf diurutkan sesuai tahun terbit jurnal dan sesuai dengan format yang telah disebutkan. Hal itu dilakukan untuk dapat mendapatkan gambaran yang komprehensif mengenai penelitian sejarah akuntansi perspektif NAH di Indonesia.

\section{HASIL DAN PEMBAHASAN}

Titik awal dimulainya penulisan sejarah akuntansi dengan menggunakan pendekatan NAH bisa diamati dari tulisan Sukoharsono and Gaffikin (1993a) yang berjudul "Power Knowledge in Accounting: Some Analysis and Thoughts on Social, Political, and Economic Forces in Accounting And Profession in Indonesia". Penelitian ini menggunakan pendekatan Power Knowledge yang dipopulerkan oleh Foucoult (1975). Pendekatan Power-knowledge digunakan sebagai alat analisis untuk dapat menguak bagaimana suatu peristiwa dapat muncul pada periode waktu tertentu. Relasi Power-knowledge ini berhubungan dengan bagaimana 
kuasa yang ada pada masa tertentu menghasilkan suatu pengetahuan. Pendekatan Power Knowledge juga disebut sebagai pendekatan relasi kuasa-pengetahuan. Kuasa dalam hal ini bukan dimaknai sebagai kekuasaan yang represif tetapi dimaknai sebagai sesuatu yang positif yang jauh dari kata tekanan dan dominasi dari kelas tertentu, negara atau kedaulatan tertentu. Kuasa lebih dimaknai sebagai strategi, kuasa dijalankan daripada dimiliki dan dilaksanakan bukan hanya sebagai kewajiban atau larangan tetapi kuasa itu menginvestasi pada diri manusia yang kemudian ditransmisikan dari satu individu ke individu lainnya dalam satu komunitas masyarakat. Kuasa menghasilkan pengetahuan dan pengetahuan muncul karena adanya relasi kuasa. Keduanya tidak bisa dipisahkan satu dengan yang lainnya. Hal ini yang kemudian digunakan oleh Poster (1982) dalam memahami bagaimana hukuman berubah pada abad ke 18 dari hukuman yang represif ke hukuman yang mendisiplinkan individu.

Konsep kuasa-pengetahuan ini kemudian digunakan oleh Sukoharsono untuk menggambarkan tentang awal kemunculan akuntansi dan profesi akuntansi di Indonesia. Sukoharsono and Gaffikin (1993b) menyebutkan bahwa awal kemunculan profesi akuntansi dan kantor akuntan publik di Indonesia tidak terlepas dari rangkaian pengaruh dari perkembangan profesi akuntan publik di Eropa terutama di Belanda dan Inggris. Dimana hal tersebut dipengaruhi oleh adanya revolusi industri di Inggris yang kemudian memberikan dampak bagi Belanda yang juga mempengaruhi cara perusahaan-perusahaan Belanda yang ada di Indonesia dalam melakukan bisnisnya. Hal tersebut bisa diamati pada era tahun 1900-1940 di Indonesia dimana permintaan akan akuntan meningkat tajam dan karena pada saat itu Pribumi Indonesia masih kurang dalam segi Pendidikan formal akuntansi maka untuk memenuhi permintaan tersebut banyak akuntanakuntan asing terutama dari Belanda dan Inggris yang masuk ke wilayah Indonesia.

Penelitian sejarah selanjutnya yang dilakukan oleh Sukoharsono berjudul "The Genesis of Accounting in Indonesia in the early of $17^{\text {th }}$ Century" yang diterbitkan pada tahun 1993 di International Journal of Accounting and Business Society. Jenis penelitian yang dilakukan oleh Sukoharsono adalah penelitian kualitatif dengan menggunakan pendekatan Arkeologi Pengetahuan yang dipopulerkan oleh Michael Foucault sebagai alat analisis untuk dapat menemukan titik awal munculnya pencatatan berpasangan di Indonesia sebagai suatu bukti eksistensi akuntansi pada awal abad ke 17 di Indonesia. Bagi Focoult Arkeologi Pengetahuan dimaknai sebagai pendekatan yang menyajikan cerita sejarah dengan cara yang berbeda dari cara pembacaan sejarah tradisional. Sejarah merupakan rangkaian cerita masa lalu yang tidak linear, diskontinu dari kejadian masa sebelumnya, terdapat banyak gaps, dan cenderung terputus-putus.Fokus arkeologi pengetahuan ada pada diskurs-diskurs kontemporer yang menyajikan kondisi riil masyarakat sebagai dasar logika kemunculan pengetahuan di tengah-tengah masyarakat.Analisis sejarah dilakukan dengan melakukan analisis diskursif pada setiap dokumenakuntansi masa lalu. Sejalan dengan itu, Sukoharsono mencoba mengaplikasikan pendekatan Arkeologi Pengetahuan untuk dapat menceritakan awal mula adanya sistem pencatatan berpasangan di Indonesia yang dimulai dengan memahami kondisi sosio ekonomi masyarakat pada masa itu.Pada awal abad ke 17, telah terjadi ekspansi perdagangan Belanda secara massif. Dampak dari adanya ekspansi tersebut adalah dikirimnya banyak kapal dagang Belanda termasuk ke Kawasan East Indies ( Kepulauan Indonesia) yang dipercaya oleh Belanda sebagai sumber kekayaan tersembunyi seperti rempah-rempah, emas, perak kayu dan kapas. Untuk mempermudah koordinasi perdagangan di wilayah Indonesia, pemerintah belanda kemudian membentuk perusahaan yang dinamakan sebagai VOC yang merupakan singkatan dari Verenidge Oostindische Compagnie. Tugas VOC di Indonesia adalah untuk membentuk suatu monopoli perdagangan dan mengintervensi urusan perpolitikan guna mempermudah bisnis VOC. Pada awal kedatangan VOC di Indonesia, beberapa perubahan bisa diamati diantaranya dibentuknya pusat perdagangan di Banten pada tahun 1609.

Selain pusat perdagangan, VOC juga membentuk pusat militer yang digunakan untuk melakukan perlawanan kepada siapa saja yang menentang VOC dan memantapkan posisi monopoli perdagangan di Indonesia. Hal tersebut kemudian memicu adanya ketidakstabilan kondisi ekononomi, sosial dan politik di wilayah nusantara karena pemerintah Belanda kemudian sedikit demi sedikit menghapus sistem pemerintahan yang berbasis kerajaan menjadi sistem pemerintahan berbasis kolonial. Perhatian utama Belanda selanjutnya adalah dengan menyuntikkan sistem perdagangan moneter dengan menggunakan mata uang Belanda sebagai alat tukarnya. Hal tersebut dilakukan oleh belanda agar dapat memudahkan mereka dalam urusan perdagangan karena sebelum kedatangan VOC di Indonesia alat tukar yang digunakan untuk kepentingan perdagangan tidaklah sama antar wilayah nusantara. Dengan standardisasi uang yang dilakukan oleh pemerintah belanda, maka hal tersebut mempermudah aktivitas perdagangan yang berdampak pada menungkatnya kompleksitas dan kebutuhan untuk melakukan pencatatan atas transaksi ekonomi yang dilakukan. Dengan semakin kompleksnya aktivitas ekonomi tersebut, hal tersebut tentu saja memberikan dampak bagi VOC. Hal yang paling dominan adalah bertambahnya kekayaan VOC karena aktivitas perdagangan yang semakin ramai yang menimbulkan masalah administrasi keuangan dan pengelolaan kekayaan. Dari titik inilah kemudian pembukuan akuntansi sangat diperlukan untuk menangani permasalahan tersebut. Pembukuan sendiri digunakan untuk melakukan perencanaan pendapatan dan pengeluaran yang tepat, kepentingan akuntabilitas atau pertanggungjelasan pengelolaan sumberdaya perusahaan dan untuk fungsi pelaporan kepada anggota VOC.

Sistem pembukuan yang pertama kali dilakukan oleh VOC bukanlah suatu sistem pembukuan yang kompleks namun sistem yang sangat sederhana dengan menggunakan single entry bookkeepingyang digunakan untuk melakukan pen- 
gorganisasian untuk mengatur pengeluaran terkait dengan masalah penggajian personel militer VOC. Dalam perkembanganya kemudian muncullah pembukuan dengan menggunakan double entry book keeping. Awal dari perkembangan double entry book keeping ini muncul karena ada perubahan kebijakan mengenai tata laksana administrasi dan keuangan. Untuk memperlancar kebijakan ini, pemerintah belanda kemudian menunjuk Gubernur Jendral Pieter sebagai penanggungjawab. Pieter kemudian mendirikan kantor akuntan di Banten. Bersamaan dengan itu, sistem pembukuan double entry book keeping mulai digunakan untuk kepentingan pelaporan keuangan perusahaan.

Berbeda dengan pembukuan double entri sekarang, pada saat itu tidak ada akun modal atau akun utang-rugi yang efektif. Akun tersebut dibuat sangat sederhana dan tidak ada akun tambahan untuk kerugian dan keuntungan secara konsisten dari berbagai akun perdagangan. Kemudian muncul bentuk neraca yag digunakan di Batavia pada tahun 1621 dan saat itu pula istilah Debit dan Kredit telah dikenal. Pada saat itu pula terdapat bentuk pembukuan penyimpanan barang, terutama dalam bentuk jurnal, buku besar dan neraca, tetapi tidak sama dengan pembukuan double entri yang dipahami saat ini. Debit dan kredit yang dimaksud saat itu dipahami sisi kredit terdiri dari akun uang, barang dagangan, bahan makanan, hutang kepada perusahaan dan berbagai penerimaan. Sedangkan sisi debit merupakan pengeluaran untuk garnisun, kapal, biaya administrasi dan hutang perusahaan. Namun, modal dan akun aset tetap masih belum ada dan dicatat dalam neraca setelah tahun 1689. Demikian juga dengan laba dan rugi tidak dilaporkan. Dalam hal akuntansi untuk mengetahui untung atau rugi dengan membandingkan antara total penerimaan penjualan yang dilakukan ke Eropa dengan total biaya peralatan, setelah itu selisihnya digunakan sebagai keuntungan atau kerugian.

Di tahun 1995, Sukoharsono Bersama dengan Gaffikin seorang professor dari University of Wollonggong Kembali melakukan penelitian sejarah akuntansi di Indonesia dengan judul "Accounting, Collonial Capitals and Liberal Order: The Case of Accounting History in Indonesia During The Dutch Colonial Period of The Mid to End of the $19^{\text {th }}$ Century". Penelitian ini berfokus pada bagaimana akuntansi berkembang pada sekitar pertengahan sampai akhir abad ke 19. Faktor-faktor apa saja yang menyebabkan perkembangan tersebut terjadi dengan cara memahami kondisi sosial ekonomi dan politik Indonesia masa itu yang didominasi oleh kolonoalisme Belanda. Penelitian Sukoharsono (1995) menyatakan bahwa adanya perubahan radikal pada kebijakan keuangan dan modal pemerintah belanda pada saat itu juga ternyata makin menyokong posisi kolonialisme Belanda pada perekonomian Indonesia. Selain itu, dengan semakin kompleksnya ekonomi pada saat itu, mulai muncul perbankan dengan basis kapitalisme di Indonesia pada sekitar tahun 1900-1940. Bank-bank tersebut merupakan bank milik Belanda seperti Javasche Bank, The NHM, NIEM. Bankbank tersebut berfokus pada aktifitas perdagangan dan sektor pertanian. Selain bank yang berasal dari Belanda, muncul juga bank yang berasal dari Inggris dan Cina yang berfokus pada kegiatan eksopr dan impor. Selain bank-bank asing tersebut, menurut Sukoharsono (1995) bank pribumi juga sudah mulai ada yaitu Bank Negara Indonesia (BNI) tetapi jangkauan bisnisnya dibatasi hanya untuk industri kecil pribumi saja. Sejalan dengan perkembangan tersebut, kebutuhan untuk menambah sumberdaya manusia juga semakin meningkat. Terutama pada saat pemerintahan Jepang yang berkuasa di Indonesia. Pada saat itu lowongan kursus Pendidikan akuntansi ditawarkan oleh pemerintah Jepang untuk memenuhi kebutuhan tenaga kerja. Sukoharsono menyebutkan ada sekitar empat kursus yang ditawarkan oleh pemerintah Jepang. Namun pada tahun 1943, Jepang tidak lagi memberikan kesempatan Pendidikan dan kursus akuntansi karena fokus dan tujuannya sudah berubah menjadi lebih fokus pada kekuasaan mereka di Indonesia. Selain menceritakan perkembangan akuntansi pada masa kolonialisme belanda dan jepang, Sukoharsono (1995) juga membahas tentang perkembangan kemunculan program studi Akuntansi yang ada di Universitas-universitas di Indonesia sebagai dampak lanjutan untuk merespon perkembangan ekonomi Indonesia pasca kemerdekaan Indoesia,Alat analisis yang digunakan untuk dapat menggambarkan perkembangan dan menjelaskan berbagai perubahan-perubahan signifikan dalam akuntansi pada saat itu adalah genealogiarkeologi pengetahuan yang juga dipopulerkan oleh Michael Foucault. Konsep genealogi-arkeologi ini digunakan untuk memahami bagaimana sebuah perubahan dalam masyarakat yang melahirkan pengetahuan baru terjadi dengan menggunakan telaah diskursif pada dokumen-dokumen masa lalu. Hal ini dilakukan untuk dapat menemukan alasan dan logika yang sesuai mengapa suatu peristiwa terjadi di masa lalu dan alasan yang mendasarinya.

Pada tahun 1998 Sukoharsono mulai melirik topik lain disamping akuntansi pada era kolonialisme, Ia mulai melakukan penelitian dengan latar penelitian yang lebih awal yaitu pada era kerajaan. Judul penelitian tersebut adalah Accounting in A Historical Transition: A Shifting Dominant belief from Hindu to Islamic Administration in Indonesia dengan menggunakan pendekatan genealogi dari Michael Foucault.Penelitian ini membahas mengenai akuntansi dalam transisi historis dari dominan administrasi Hindu ke Islam di Indonesia. Fokus penelitian ini adalah tentang bagaimana awal perkembangan Islam di nusantara dapat memberi pengaruh dalam hal sosial maupun ekonomi. Disebutkan bahwa kedatangan Islam saat itu telah membuat penduduk asli Indonesia memperoleh pengetahuan baru tentang cara penulisan dan penggunaan koin untuk kegiatan transaksi ekonomi. Islam mempraktikkan pertukaran perdagangan untuk memenuhi kebutuhan mereka sehingga kontak perdagangan dengan negara lain sering terjadi. Mulanya, seni menulis dan pencatatan administrasi diketahui dari beberapa bukti peninggalan kepada Raja Mulawarman di Kutai Kalimantan. Akan tetapi, ketika Islam masuk nusantara seni menulis dan pencatatan administrasi semakin berkembang dengan masuknya ilmu-ilmu pengetahuan. Islam juga membawa perkembangan kertas sebagai 
pengganti daun lontar untuk keperluan menulis pada masa Budha-Hindu. Bentuk sederhana dari menulis agar dapat dijangkau masyarakat Indonesia saat itu adalah melalui abjad kuno yang kemudian mengadopsi abjad latin. Perkembangan khusus akuntansi dalam bentuk penulisan pada awalnya digunakan untuk tujuan administrasi dan pertanggungjawaban pengumpulan pajak secara sederhana di pengadilan kerajaan-kerajaan Islam. Selain itu sistem numerik juga semakin berkembang seiring berkembangnya pula Islam di nusantara. Kegiatan administrasi dan perdagangan Islam juga berkembang pesat terutama di Sumatera dan Jawa. Sebagai akibatnya, kebutuhan substansial pengeluaran negara akan meningkat dan tidak dapat lagi dipenuhi hanya dengan mengandalkan sistem sukarela (sedekah). Perkembangan sumber pendapatan tetap di Jawa diperoleh dari zakat, pajak tanah dan upeti. Sedangkan di Sumatera didasarkan pada pendapatan dari perdagangan emas.

Di tahun 2000, Sukoharsono (2000) kembali melanjutkan penelitian, kali ini Sukoharsono kembali lagi meneliti akuntansi pada masa-masa setelah kemerdekaan Indonesia. Judul penelitiannya adalah "Bookkeeping to Professional Accounting: A University Power in Indonesia". Penelitian ini mencoba menjelaskan mengenai bagaimana transisi masa kolonial ke masa kemerdekaan Indonesia mempengaruhi akuntansi di Indonesia. Sukoharono menjelaskan secara sistematis dengan menggunakan pemahaman konteks sosial dan alat analisis power-knowledge sebagai basis untuk memahami perkembangan akuntansi dan profesi akuntansi di Indonesia pasca Indonesia Merdeka. Sukoharsono (2000) menyebutkan bahwa pada era awal kemerdekaan Indonesia, praktik akuntansi di Indonesia masih belum mapan.Hal tersebut menyebabkan praktik pelaporan akuntansi di Indonesia menjadi suatu yang belum begitu popular dilakukan. Walaupun demikian, beberapa perusahaan yang tercatat menjadi emiten aktif di Bursa Efek Indonesia dan beberapa perusahaan asing tetap melakukan pelaporan eksternal akuntansi. Sejalan dengan itu, pada tahun 1945 Indonesia diketahui belum mempunyai standar akuntansi sedikit perusahaan yang melakukannya, terutama yang terdaftar di bursa saham dan perusahaan asing. Lahirnya pembaharuan terkait profesi akuntan di Indonesia ditandai dengan pengesahan UU No 341954 tentang hak praktek umum dan penggunaan akreditasi gelar akuntansi. Dengan adanya UU tersebut orang Indonesia dapat memulai upaya pada pengembangan akuntansi. Melalui UU tersebut pula sebuah asosiasi yang menaungi untuk profesi akuntan didirikan yakni Ikatan Akuntan Indonesia pada tahun 1957 dengan jumlah anggotanya hanya 9 orang. Sampai dengan tahun 1965 jumlah akuntan yang terdaftar sebanyak 232 . Jumlah tersebut masih sangat kecil sehingga dalam pengakuan di dunia bisnis maupun akademis mendapat kurang perhatian. Namun di tahun 1966 peningkatan permintaan jasa akuntan professional mengalami peningkatan karena kebijakan yang dipilih Soeharto pada saat itu. Sehingga kolaborasi antar kantor akuntan Indonesia dengan asing juga menjadi terjalin. Disebutkan pada tahun 1973 melalui sebuah kon- gres yang dilakukan menetapkan prinsip akuntansi Indonesia serupa denga GAAP Indonesia dan kode etik profesi akuntan. Sejak awal-awal kemerdekaan, Indonesia masih sulit untuk menetapkan model akuntansi sendiri yang tidak terpengaruh oleh sistem akuntansi asing. Pengaruh AS dalam konsep akuntansi di perguruan tinggi Indonesia juga terjadi. Profesi akuntansi dan Pendidikan akuntansi di perguuran tinggi memiliki keterkaitan dan berjalan berdampingan.rofesi akuntan membutuhkan lulusan dengan kualifikasi tinggi untuk memenuhi kebutuhan sumber daya, dan di perguruan tinggi juga membutuhkan permintaan yang stabil untuk kelangsungan hidup lulusannya. Menurut sejarah, pembelajaran terkait pembukuan sudah diajarkan di sekolah belanda yang ada di Indonesia tetapi terbatas untuk masyarakat Indonesia tidak semua bisa mencicipinya. Kemudian juga guru privat dalam pebukuan diberikan belanda untuk kantor pajak, kantor audit, dan lainnya. Untuk ujian akhir dan sertifikasi juga terdapat program sendiri. Pada masa colonial belanda pembukuan dilakukan untuk mengetahui gambaran keuntungan dengan cara membandingkan saldo keuangan pada awal dan akhir transaksi. Kemudian setelah Indonesia merdeka, pembukuan tidak lagi hanya sekedar mengetahui keuntungan tetapi lebih kompleks. Dalam praktik audit, secara umum perkembangannya terkait dengan aktivitas perusahaan swasta dengan pengaruh dari perusahaan AS yang diterapkan juga ke sektor public di bawah kendali pemerintah. Dalam hal ini, mengacu pada UU kewajiban dan fungsi control untuk memberikan informasi tentang administrasi keuangan operasi pemerintah.

Pendidikan formal akuntansi pertama dilakukan di Universitas Indonesia tahun 1952. Akuntansi yang sistematis diajrakan untuk memenuhi persyaratan standar komunitas bisnis. Melalui universitas, program komprehesif dari kursus akuntansi dapat dimungkinkan diterapkan pengetahuan umum tentang ekonomi, keterampilan akuntansi dengan Teknik khusus, praktik audit, dan lainnya yang berkaitan dengan akuntansi. Tak hanya Universitas Indonesia, perguruan tinggi lainnya juga telah mengajarkan Pendidikan formal akuntansi, seperti Universitas Padjajaran, Universitas Sumatera Utara, Universitas Airlangga, Universitas Gadjah Mada, Universitas Sriwijaya. Gelar sarjana yang didapat setelah lulus dalam Pendidikan akuntansi di perguruan tinggi diberikan dan memenuhi syarat untuk mendaftar sebagai akuntan setelah menyelesaikan 3 tahun bekerja di kantor pemerintah. Dalam perkembangannya, perguruan tinggi menjadi institusi dominan dalam menghasilkan akuntan.

Pengembangan kebijakan nasional terjadi signifikan tentang Pendidikan akuntansi yang merupakan kebijakan dari pemerintah tentang keseragaman Pendidikan akuntansi di perguruan tinggi pada tahun 1975 . Tujuannya untuk memastikan keseragaman akuntan yang lulus dari standar kurikulum yang sama. Perhatian pemerintah terkait Pendidikan akuntansi sangat tinggi hingga melakukan beberapa Kerjasama dengan institusi luar negeri untuk meningkatkan kualitas akuntansi di perguruan tinggi. Pendidikan akuntan untuk pemerintah dilaksanakan oleh Sekolah Negeri untuk Auditor Pemerintah 
(STAN) yang dimiliki oleh kementerian keuangan dan disetujui oleh kementerian Pendidikan dan kebudayaan yang berstatus sarjana tetapi tidak memberikan gelar seperti pada universitas. Kemudian setelah selesai, para lulusan STAN menjadi akuntan terdaftar menurut UU No 34 tahun 1954. Hal ini berbeda dengan lulusan dari universitas yang harus menjalani kuliah tambahan ujian professional yang diberikan komite ahli yang ditunjuk Menteri Pendidikan dan kebudayaan. Hingga tahun 1978 PTN dan STAN sudah meluluskan 1.763 akuntan dimana jumlah tersebut sebanyak 642 lulusan akuntan STAN. Sejak mata kuliah akuntansi dikembangkan dalam sistem universitas, angka akuntan yang lulus dari universitas dapat bekerja sebagai akuntan internal dan terus mengalami perkembangan.

Setelah rentetan penelitian akuntansi yang dilakukan oleh Sukoharsono, pada tahun 2006 muncul penelitian sejarah yang dilakukan oleh Indra Bastian. Berbeda dengan pendekatan yang digunakan oleh Sukoharsomo yang menggunakan serangkaian karya Michael Foucault sebagai alat analisis, Bastian (2014) menggunakan pendekatan lain yaitu pendekatan kritis untuk meneliti peran akuntansi di masa lalu. Judul penelitiannya adalah"A Review of The Accounting Role in Ancient and Colonial Period: A Case Study of Indonesian Telecomunication Industry"Tujuan penelitian ini disebutkan untuk memperjelas peran akuntansi di industri telekomunikasi dan menjajaki privatisasi dalam konteks telekomunikasi. Metode yang digunakan untuk penelitian ini adalah dengan critical review untuk menunjang tujuan studi. Dalam masing-masing periode, dokumen akuntansi menunjukkan tahapan telekomunikasi dari kerajaan kuno hingga masa kolonialisme. Pada masa kerajaan kuno, proses akuntansi menghasilkan upeti. Hal itu akan berfungsi sebagai bahan evaluasi dan symbol kesetiaan. Upeti akan dikumpulkan kepada raja melalui bendaharanya. Ini berarti pada masa kerajaan kuno, proses akuntansi lebih ditujukan untuk kegiatan sosial. Sedangkan pada masa penjajahan Belanda, produknya berupa koin. Koin tersebut merupakan simbol dari sistem moneter dan monopoli perdagangan. Selain itu, manajemen VOC juga menetapkan beberapa bentuk produk lainnya seperti laporan laba rugi, catatan persediaan dan tarif. Laporan laba rugi dan catatan persediaan merupakan jenis pelaporan dan tarif adalah hasil dari perhitungan akuntansi. Hal tersebut mengasumsikan bahwa praktik akuntansi keuangan telah diterapkan terlebih dahulu yang kemudian diikuti dengan praktik akuntansi biaya. Dalam masa ini, kekuasaan berada di tangan administrator. Kemudian pada masa pendudukan Jepang,produk akuntansi tidak jauh berbeda dengan Belanda yaitu laporan laba rugi, catatan persediaan dan tarif. Dalam masa itu sistem akuntansi difungsikan sebagai evaluasi yang mendukung strategi militer dan kekuasaan berada di tangan komandan militer. Fokus kerajaan kuno dalam menerapkan akuntansi saat itu adalah sebagai bentuk kontrol raja terhadap loyalitas setiap daerah, masa penjajahan Belanda fokus untuk perhitungan pendapatan sedangkan pada masa Jepang fokus yang dipilih adalah untuk militer. Setiap periode memiliki masalah akun- tansi yang berbeda-beda. Masalah teknis terjadi di periode kerajaan kuno dan penjajahan Belanda. Kemudian masalah perspektif terjadi di periode pendudukan Jepang. Masalah lainnya juga terjadi saat itu (kecuali periode kerajaan kuno) disebabkan kurangnya pemahaman akuntansi sebagai suatu konsep dan praktik karena orang Indonesia saat itu belum banyak yang mempelajari akuntansi, terutama dalam industri telekomunikasi, masalah ini berlanjut hingga tahun 1990-an. Sehingga dapat dikatakan masalah utama akuntansi di industri telekomunikasi adalah sumber daya manusia.

Di tahun 2008, kali ini Sukoharsono melakukan penelitian sejarah akuntansi dengan mengambil setting waktu masa kerajaan Singosari Berjudul Accounting in the Golden Age of Singosari Kingdom: A Foucauldian Perspective. Penelitian ini bercerita tentang implementasi akuntansi pada masa keemasan kerajaan Singosari dengan mengadopsi pendekatan Foucauldian untuk menunjukkan kompleksitas akuntansi dari kekuatan dan struktur pengetahuan dalam sebuah masyarakat. Fokus penelitiannya ada pada bagaimana praktik akuntansi pada masa kerajaan Singosari dilakukan. Pemahaman akuntansi pada masa kerajaan Singosari ini dimulai dengan meletakkan akuntansi sebagai praktik sosial. Artinya, bentuk akuntansi yang ada pada saat itu tidak bisa disamakan bahkan dengan bentuk praktik akuntansi yang ada di abad ke 17 maupun abad-abad selanjutnya yang jauh lebih kompleks. Hal tersebut karena kondisi sosial dan ekonomi pada saat itu berbeda. Pada masa kerajaan Singosari, praktik akuntansi yang dilakukan bukan berfokus pada praktik akuntansi modern seperti yang ada pada kehidupan modern dimana produk akuntansi yang paling nyata adalah laporan keuangan.Akuntansi pada masa Singosari ditelaah dengan mengidentifikasikan terlebih dahulu komponen pembentuk akuntansi. Beberapa komponen pembentuk akuntansi diantaranya adalah sistem angka, sistem penulisan dan uang. Dijelaskan oleh Sukoharsono dan Lutfillah bahwa ketiga komponen tersebut sangat penting dalam pembentukan dan pengimplementasian akuntansi pada masa kerajaan Singosari. Sistem angka misalnya, dari bukti prasasti yang ditemukan menunjukkan bahwa terdapat pencatatan transaksi khususnya transaksi perdagangan di pasar menggunakan angka Jawa Kuno. Pada saat itu, para penjual hanya menyusun akunnya untuk kepentingan dokumentasi sendiri dengan bahasa yang mudah dipahami. Selain itu, media penulisan yang digunakan juga menggunakan yang mudah sehingga dapat mengetahui biaya dan keuntungan dengan mudah pula. Hal ini memudahkan mereka untuk mengambil keputusan terkait masa depan usahanya. Penggunaan mata uang di pasar pada era Singosari adalah salah satunya Koin Tembaga Cina selain uang emas dan perak. Selain itu, diperkirakan telah ada tradisi menabung di zaman Singosari yang diperkuat dengan bukti adanya lubang pada kotak tabungan yang berarti uang yang disimpan adalah koin.

Kemudian penelitian sejarah akuntansi lainnya yang berjudul Construction of Agriculture Accounting Practices in the Reign of King Udayana Bali: Ethnoarchaeological Approach dilakukan Budiasih (2012) menceritakan mengenai 
bagaimana praktek akuntansi pertanian dalam masa pemerintahan Raja Udayana di Bali. Penelitian ini merupakan penelitian kualitatif dengan menggunakan pendekatan analisis etnoarchaeological. Penelitian ini juga berfokus pada pembahasan akuntansi pertanian periode 989-1011 Masehi yang diyakini lebih menarik karena saat itu akuntansi pertanian telah dipahami dalam berbagai bentuk, termasuk pembagian sistem pencatatan, sistem irigasi, pajak pertanian untuk mencatat hasil komoditas pertanian dengan model yang sederhana. Kemajuan pemerintahan Raja Udayana dimulai dari kehidupan masyarakatnya dengan mata pencaharian berburu dan bercocok tanam sehingga pada masa itu masyarakat sudah tinggal di satu tempat dan tidak nomaden seperti zaman prasejarah. Dari situ praktik akuntansi pertanian tergambar dalam interaksi dengan kehidupan masyarakat pada saat itu yang mencerminkan telah memahami kehidupan perekonomian yang lebih kompleks dan terstruktur. Salah satunya terbukti dari pemungutan pajak yang dilakukan dalam hal pembayaran pajak atas tanah pertanian. Lahan pertanian juga telah diolah dan diproses dengan cara yang lebih baik yang artinya saat itu Bali sudah mengenal sistem pengairan sawah dengan cukup baik dan teratur. Sehingga kedudukan kepala sistem irigasi sawah juga telah dikenakan pemungutan pajak. Selain itu, telah diatur juga sistem bagi hasil antara pemilik sawah dengan pekerjanya. Berdasarkan data yang ditemukan, untuk tanaman padi pembagian dilakukan sebesar $2 / 3$ untuk pemilik sawah dan $1 / 3$ untuk pekerjanya. Kebalikan dari hal tersebut, untuk tanaman lainnya seperti kacang-kacangan pembagian sebesar $2 / 3$ didapat oleh pekerja, sedangkan $1 / 3$ akan didapat pemilik. Pendaftaran pengalihan kepemilikan tanah ladang dan kebun oleh kerajaan kepada masyarakat saat itu juga merupakan transaksi jual beli dimana sebagai salah satu bentuk penerapan praktik akuntansi.

Selanjutnya Budiasih (2012) dalam penelitiannya yang berjudul Accounting Practices and The Use of Money in The Reign of King Udayana in Bali: An Ethnoarcheological Approach juga melakukan penelitian terkait praktik akuntansi dan penggunaan uang dalam pemerintahan Raja Udayana di Bali dengan pendekatan etnoarkeologi. Tujuan penelitian ini untuk mengeksplorasi keberadaan praktik akuntansi dan penggunaan uang pada masa pemerintahan Raja Udayana yang dilakukan dengan pendekatan etnoarkeologi. Penelitian ini merupakan penelitian kualitatif dengan pendekatan etnoarkeologi dalam menganalisis masalah yang diajukan. Pada masa ini, keberadaan akuntansi telah ada dan diketahui keberadaannya. Akuntansi dipahami mulai dari kegiatan transaksi ekonomi di pasar tradisional dan penggunaan mata uang, hingga melakukan model pencatatan yang sederhana. Disebutkan bahwa Raja Udayana saat itu menetapkan nilainilai religious sebagai dasar transaksi sosial dan ekonomi masyarakat. Penggunaan mata uang sebagai alat tukar dan satuan moneter sangat erat kaitannya dengan sejarah praktik akuntansi. Kerajaan menciptakan mata uang emas dan perak dengan berbagai satuan dan juga menggunakan symbolsimbol tertentu yang memiliki arti signifikan. Symbol dua pola biji yang sama antara sisi kiri dan kanan pada koin emas menggambarkan kehidupan keseimbangan antara lahir dan batin. Begitu juga dengan pola empat kelopak bunga cendana yang tercetak pada mata uang perak sebagai pohon keramat menggambarkan empat mata uang penjuru yang diyakini masyarakat saat itu bahwa Dewa Dewi sebagai pelindung orang-orang yang mempercayai kebesaran mereka. Selain itu, dalam bukti yang ditemukan praktik akuntansi pada masa itu menggunakan praktik perimbangan dimana transaksi yang berkaitan antara kerajaan dan penduduknya menunjukkan bagaimana kerajaan sangat memahami makna hidup sejahtera dan seimbang.

Kembali terdapat penelitian sejarah akuntansi yang dilakukan oleh Lutfillah and Sukoharsono (2013) yang berjudul Historigrafi Akuntansi Indonesia Masa Mataram Kuno (Abad VII-XI Masehi). Fokusnya adalah pada aspek pembahasan mengenai akuntansi perpajakan. Metode yang digunakan untuk penelitian ini adalah sosial arkeologi dimana metode ini didasarkan pada penjelasan pada temuan sumber sejarah pada masa Kerajaan Mataram kuno dan keterkaitannya dengan keadaan sosial dimana akuntansi perpajakan dipraktikkan pada saat itu. Masa Kerajaan Mataram kuno pajak menjadi salah satu sumber pendapatan terbesar. Pemungutan pajak dikumpulkan melalui beberapa orang yang telah diberi wewenang sebelumnya oleh raja untuk kemudian sampai pada kerajaan. Biasanya pajak yang harus dibayar penduduk diserahkan kepada kerajaan setiap selesai panen hasil bumi. Selain membayar pajak, penduduk juga diharuskan untuk melakukan kerja bakti. Kedua aktivitas tersebut akan menjalin hubungan sosial antara kerajaan dengan penduduk sebagai wajib pajak. Diketahui pada saat itu selain pajak hasil bumi dan pajak tanah, rakyat yang berprofesi sebagai pedagang dan pengrajin dipungut pajak perdagangan dan pajak usaha kerajinan. Di sisi lain juga dijelaskan bahwa terdapat bukti yang mengatakan bahwa rakyat yang berprofesi sebagai seniman-seniwati diwajibkan untuk membayar pajak. Kasus penyelewengan pajak ternyata juga telah terjadi pada pemungutan pajak masa itu yang beruntungnya segera diketahui pihak kerajaan dan diselesaikan. Tak hanya kasus tersebut, ditemukan juga kasus-kasus terkait pajak yang menarik lainnya misalnya, kasus revisi pajak, kasus pembebasan pajak kerajaan, kasus penolakan pajak.

Serupa dengan penelitian sejarah akuntansi sebelumnya, Budiasih (2014) juga melakukan penelitian dengan judul Fenomena Akuntabilitas Perpajakan Pada Jaman Bali Kuno: Suatu Studi Interpretif bercerita terkait fenomena akuntabilitas perpajakan pada jaman Bali kuno (IX-XV Masehi). Menggunakan jenis penelitian kualitatif dengan metode etnoarkeologi untuk melakukan analisis masalah yang diteliti. Tujuan penelitian ini adalah mengeksplorasi akuntabilitas perpajakan yang terjadi yang berkaitan dengan aspek sosial kultural pada masa itu dalam hal hubungan antara raja dengan rakyatnya melalui mekanisme perpajakan. Mekanisme pemungutan pajak saat jaman Bali kuno dijelaskan telah diatur sedemikian rupa baik mengenai waktu untuk melakukan pembayaran, besarnya pajak yang dikenakan dan batasan pembebasan pen- 
genaan pajak serta sistem pemungutannya. Semua itu tidak dapat disamakan antara satu dengan yang lainnya disebabkan beberapa hal misalnya perbedaan waktu hasil panen, intensitas kegiatan yang dilakukan dan tergantung pada jenis pengenaan pajaknya. Pemungutan pajak dilakukan dari tingkat bawah dimana rakyat yang membayar pajak melalui pegawai pemungut pajak sebagai perantara penyetoran pajak hingga akhirnya diterima raja sebagai bentuk pertanggungjawaban. Fenomena akuntabilitas yang terlihat pada jaman Bali kuno juga terkait administrasi dan akuntabilitas perpajakannya. Pegawai pemungut pajak melakukan pencatatan administrasi pembayaran pajak sebagai bentuk pertanggungjawaban kepada raja melalui bendahara kerajaan. Setoran pembayaran pajak yang telah dikumpulkan merupakan pendapatan terbesar kerajaan yang nantinya akan digunakan untuk membiayai seluruh pengeluaran yang berhubungan dengan kerajaan dan pembangunan sarana dan prasarana yang dibutuhkan rakyat misalnya untuk pembangunan jalan, pura, pasar, pemandian, dan lain sebagainya. Diketahui pada jaman Bali kuno ini raja juga memberikan kebijakan pajak untuk meringankan pembayaran pajak bagi beberapa masyarakat tertentu.

Rosyinadia et al. (2014) dalam penelitiannya yang berjudul Accounting and Accountability Strategies of Gajah Mada's Government: Analysis of Power-Knowledge bercerita tentang strategi akuntansi dan akuntabilitas pada masa pemerintahan Gajah Mada dilihat dari analisis kekuasaan dan pengetahuan. Metode penelitian kualitatif yang merupakan penelitian paradigma postmodemistik kebalikan dari modernistik. digunakan dalam penelitian ini. Kerangka Faucouldian digunakan sebagai alat dan strategi untuk mengungkap akuntansi dan akuntabilitas pada masa Majapahit dalam kepemimpinan Gajah Mada. Terdapat dua prinsip kerangka ilmu pengetahuan Foucault yaitu genealogy dan archaeology. Fokus penelitian tertuju pada perdagangan, perpajakan dan akuntabilitas Kerajaan Majapahit pada masa Gajah Mada.Gajah Mada memiliki peran dalam membentuk pola akuntansi kerajaan. Kondisi ekonomi Majapahit yang terbatas pada pertanian dan industri kecil, membuat Gajah Mada merumuskan strategi pengembangan ekonomi masyarakat. Masyarakat Majapahit telah mengenal dan menerapkan akuntansi dalam kegiatan ekonominya. Hal tersebut dibuktikan dengan ditemukannya mata uang yang menjadi alat tukar dalam kegiatan perekonomian. Kegiatan perdagangan masa Majapahit tidak hanya terjadi antar masyarakat lokal akan tetapi sudah dilakukan juga secara internasional. Selain itu, pajak menjadi pendapatan terbesar kerjaan Majapahit. Pajak diterima dari barang dan jasa yang dipungut dari masyarakat. Regulasi yang mengatur terkait perpajakan masa itu juga telah dibuat peraturan perundangundangan untuk mengatur segala sengketa dan sanksi yang diberikan dalam bentuk denda. Terdapat jenis-jenis pajak pada masa Majapahit yaitu pajak perdagangan, pajak untuk orang asing, pajak keluar-premit, pajak tanah dan pajak seni. Pendapatan yang diterima kerajaan dari pajak akan dikembalikan kepada rakyat dalam bentuk membangun infrastruktur seperti jalan, jembatan, tempat ibadah, atau untuk membayar gaji pejabat kerajaan. Tidak seluruh masyarakat dibebankan untuk membayar pajak kepada kerajaan. Ada beberapa daerah yang dibebaskan akan perpajakan seperti pengabdian kepada masyarakat, pajak atas pembuatan/penjualan batako, iuran untuk perbaikan jalan.

Kemudian penelitian lainnya dilakukan oleh Lutfillah (2014) dengan judul Akuntansi dalam Penetapan Sima Masa Jawa Kuno. Penelitian ini berfokus pada praktik akuntansi penetapan Sima di masa Jawa kuno sehingga tujuan penelitian ini adalah mengungkap praktik akuntansi penetapan Sima pada masa Jawa kuno. Sumber data berasal dari data arkeologi historis. Untuk mengembangkan penafsiran dari sumber tertulis menjadi relevan dilakukan dengan aliran arkeologi konteks. Disebutkan aliran ini tidak terpaku lagi pada sebuah teori akan tetapi, percaya pada pandangan kekhususan sejarah atau relativisme budaya. Dalam praktik akuntansi, penetapan Sima memiliki nilai luhur yang memiliki ciri khas budaya Indonesia pada masa Jawa kuno. Penetapan Sima dilakukan raja sebagai bentuk penghargaan kepada daerah tertentu yang tujuannya adalah untuk kegiatan keagamaan. Untuk memperkuat penetapan Sima dibuat piagam yang ditulis dalam prasasti oleh juru catat (citralekha). Citralekha mempunyai peranan dan fungsi sebagaimana akuntan pada masa sekarang. Hal ini dilakukan citralekha sebagai bentuk transparansi dan akuntabilitasnya yang diibaratkan sebagai akuntan di masa itu. Tentu saja dalam penetapannya berbagai macam ritual dilakukan. Mulai dari pemberian hadiah, berdoa kepada sang pencipta, pembacaan peraturan Sima yang berisi mantra dan perjanjian. Pengucapan sumpah dan mantra mempunyai tujuan untuk menciptakan suasana yang aman dan damai di daerah Sima ditetapkan. Dimana nantinya akan membangun kesejahteraan raja sehingga mengutamakan kepentingan rakyatnya. Besarnya biaya penetapan Sima dibandingkan dengan pendapatan Sima, dilihat sebagai suatu kebutuhan sebagai sarana penyucian diri pengikutnya.

Penelitian sejarah akuntansi yang dilakukan oleh Lutfillah et al. (2016) dengan judul Revealing the Accounting Existence Through Debt-Receivable Practice at Majapahit Kingdom Era (1350) menceritakan tentang mengungkap eksistensi akuntansi melalui praktik hutang piutang di masa kerajaan Majapahit tahun 1350. Selain untuk mengeksplorasi praktik akuntansi hutang piutang yang dilakukan masa itu, tujuan lainnya adalah untuk menemukan nilai di balik penggunaan hutang piutang. Metode yang digunakan dalam penelitian ini adalah kualitatif historis dan dianalisis apabila data yang ada akan memberikan makna. Praktik akuntansi hutang piutang di masa kerajaan Majapahit dapat dibagi ke dalam beberapa dimensi yaitu, sosial, ekonomi dan budaya. Dalam dimensi sosial, hutang piutang yang dipraktekkan masyarakat masa kerajaan Majapahit merupakan bentuk pinjam meminjam yang diibaratkan sebagai gotong royong masyarakat. Kemudian dalam dimensi ekonomi, hutang piutang merupakan bentuk transaksi ekonomi dimana masyarakatnya dapat menukar komoditas ekonominya seperti uang logam maupun hasil pertanian. Sedangkan untuk dimensi budaya, hutang 
piutang dijadikan bentuk kepercayaan dan nilai-nilai spiritual ada diantara setiap orang sebagai alat untuk mengikat persaudaraan mereka. Selain itu, dalam praktik hutang piutang saat itu kepercayaan dan nilai-nilai spiritual merupakan bentuk pertanggungjawaban debitur kepada sesama dan Tuhan sehingga hal tersebut harus dengan sendirinya disadari bahwa hutang adalah amanah yang harus dikembalikan karena hutang piutang bukan hanya kesepakatan antara debitur dengan kreditur tetapi juga dengan Tuhan. Hal yang mendasari praktik hutang piutang pada masa Majapahit lebih mengedepankan kepentingan orang lain daripada diri sendiri.

Selanjutnya penelitian yang dilakukan oleh Budiasih (2016) dengan judul Social and Environment Accounting Practices at the Time of the Ancient Bali mengungkapkan bagaimana praktik akuntansi sosial dan lingkungan pada masa Bali kuno. Praktik akuntansi masa lampau yang menjadi fokus penelitian ini adalah praktik akuntansi sosial dan lingkungan yang terjadi pada saat masa Bali kuno tahun 1-1500 Masehi. Keberhasilan pertanian sebagai sektor kehidupan yang dominan pada saat itu mengantarkan kerajaan Bali kuno ke masa puncaknya. Adanya berbagai pencatatan dan pelaporan kegiatan sosial dan lingkungan yang dapat diukur dengan nilai mata uang saat itu menunjukkan bahwa kegiatan tersebut mengandung nilai akuntansi. Penelitian ini merupakan penelitian kualitatif dengan menggunakan fenomenologi dengan pendekatan etnoarkeologi dalam menganalisis masalah yang disajikan. Praktik akuntansi sosial dan lingkungan pada masa Bali kuno telah dipahami dalam berbagai bentuk, antara lain sistem pencatatan irigasi, sistem pencatatan hasil komoditas pertanian dengan model pencatatan yang sederhana. Sistem bagi hasil bagi pemilik dan penggarap sawah ditentukan sebesar $2 / 3$ untuk pemilik sawah dan $1 / 3$ untuk penggarap yang berlaku untuk tanaman padi. Sedangkan untuk tanaman seperti kacang-kacangan sebesar 2/3 untuk penggarap dan 1/3 didapat pemilik. Praktik akuntansi konstruksi yang berkaitan dengan sosial dan lingkungan diibaratkan sebagai akuntansi pertanian yang berkaitan dengan konsep mengenai air.

Penelitian sejarah akuntansi selanjutnya dapat dilihat dari penelitian yang dilakukan oleh Widhianningrum et al. (2019) dengan judul Social Accounting and Ancient Javanese Society: The Case of Borobudur Temple yang bercerita mengenai akuntansi sosial pada masyarakat jawa kuno dilihat melalui kasus candi Borobudur. Penelitian ini menggunakan pendekatan kualitatif dan interpretatif. Kemudian dianalisis secara deskriptif kualitatif dan diinterpretasikan untuk mengetahui gambaran umum akuntansi sosial yang terdapat di dalam relief karmavibhangga. Disebutkan pemandangan relief tersebut menampakkan keadaan kerajaan Mataram saat itu memiliki tanah yang subur yang memungkinkan rakyatnya bekerja sebagai petani. Mataram kuno dikenal sebagai kerajaan agraris yang bertumpu pada pertanian yang melimpah dan didukung kegiatan perdagangan untuk menunjang perekonomiannya. Sebagai bentuk interaksi manusia dengan lingkungan, perdagangan berjalan melalui pasar sebagai sarana penunjang dengan sistem satu siklus sepasar dimana artinya kegiatan perdanganan di pasar terjadi minimal lima hari sekali. Seiring dengan meningkatnya aktivitas dan sentra perdagangan di beberapa kawasan, kerajaan Mataram mengatur pertumbuhan kekayaan dengan mendirikan sima. Hal ini dilakukan untuk mengidentifikasi banyakanya pergeseran pola produksi dan konsumsi di Jawa yang berdampak panjang pada masyarakat Jawa. Pada masa ini juga pajak telah dikenalkan dimana pajak tersebut dikeluarkan oleh raja untuk rakyatnya sebagai bentuk mendukung hubungan baik satu sama lain. Pajak tersebut akan digunakan sebagai pembiayaan infrastruktur, pembiayaan kesejahteraan dan keselamatan masyarakat, serta pembiayaan umum lainnya. Berdasarkan ajaran moral umat Buddha, keuntungan tidak dianggap sebagai keinginan untuk memenuhi kepentingan diri sendiri, melainkan sebagai kebutuhan untuk sesama. Kualitas perekonomian tidak hanya dilihat dari besarnya keuntungan tetapi juga dari cara perolehan dan pendistribusiannya. Akuntansi sosial pada jaman Jawa kuno diartikan sebagai perwujudan perjalanan spiritual manusia untuk membebaskan dirinya dari keinginan duniawi dalam pencarian tertinggi. Akuntansi sosial akhirnya hadir sebagai bentuk kontrol ekonomi dan mediator konflik antar manusia, kebutuhannya, dan lingkungannya.

Perkembangan Akuntansi yang telah dipaparkan diatas dapat dirangkum dalam Tabel 1 di bawah ini:

[Table 1 about here.]

\section{REFLEKSI DAN AGENDA RISET MENDATANG}

Dari beberapa penelitian yang telah dipaparkan diatas, kita bisa memahami bahwa penelitian sejarah akuntansi dengan menggunakan pendekatan New Accounting History selalu menempatkan kondisi sosial, politik, ekonomi masyarakat untuk dapat mengetahui bagaimana sebenarnya praktik akuntansi pada masa itu. Alat analisis yang digunakan juga disesuaikan dengan bagaimana cerita sejarah akan disampaikan. Dapat diamati bahwa alat analisis yang digunakan pada penelitianpenelitian yang dilakukan oleh Sukoharsono menggunakan relasi kuasa-pengetahuan yang digunakan oleh Michael Foucault untuk membedah asal usul munculnya suatu perubahan yang memunculkan ilmu pengetahuan dalam suatu masyarakat. Untuk dapat memahami hal tersebut, Foucault berfokus pada wacana-wacana dalam dokumen-dokumen yang diproduksi pada masa itu. Hal tersebut merupakan ciri khas utama pendekatan sejarah dengan menggunakan uraian akuntansi secara genealogi atau secara asasl usulnya dengan mepertimbangkan kondisi masyarakat pada titik tertentu.

Sama halnya dengan penelitian sukoharsono, penelitianpenelitian yang dilakukan oleh Budiasih juga menggunakan pendekatan ini dalam penelitiannya namun cara pengambilan data dilakukan dengan menggunakan pendekatan etno arkeologi dan pendekatan arkeologi. Hal tersebut karena Bali sampai dengan saat ini masih mempertahankan budayanya 
berbeda dengan daerah lain di Indonesia dimana budaya masa lalunya sudah cenderung luntur termakan oleh Zaman. Beberapa peninggalan arkeologis di Bali juga Sebagian besar dipertahankan sehingga data arkeologis bisa dengan mudah di akses oleh peneliti. Agak berbeda dengan penelitian lain, penelitian yang dilakukanoleh Bastian (2014) dilakukan dengan menggunakan pendekatan critical review, walapun demikian dalam penelitiannya juga menggunakan alur berfikir genealogi dimana ia membagi telaahnya kedalam periode-periode yang berbeda sesuai dengan perkembangan politik dan ekonomi masyarakat pada masa itu sebagai fokus pembahasannya. Sejalan dengan itu, penelitian-penelitian lainnya juga menggunakan cara yang sama walaupun pendekatan dalam memperoleh data atau penginterpretasian datanya berbeda.

Jika dilihat pada arah perkembangannya, Sukoharsono sudah melakukaan telaah secara mendalam pada bagaimana perkembangan akuntansi pada masa penjajahan Belanda sampai dengan era awal kemerdekaan, Sukoharsono juga telah menganalisis beberapa penelitian akuntansi masa kuno dengan berfokus pada kerajaan-kerajaan di yang ada di tanah Jawa khususnya wilayah jawa timur. Daerah kerajaan yang mungkin masih bisa diteliti adalah pada kerajaan-kerajaan yang berkembang di wilayah Jawa Barat. Setelah Jawa, praktik akuntansi di Bali juga telah di eksplorasi. Indonesia sendiri merupakan negara dengan banyak kerajaan dan banyak dinamika. Kerajaan di Indonesia pernah mengalami masa dominasi Hindu Budha lalu berpindah ke era Keislaman. Dengan adanya perpindahan tersebut juga berpotensi menimbulkan perbedaan praktik akuntansi di Indonesia. Sukoharsono sendiri sudah mengesplorasi faktor-faktor pembentuk akuntansi pada era perpindahan dari dominasi Hindu Budha ke Islam namun bagaimana praktik akuntansi spesifik pada

\section{REFERENCES}

Bastian, I. (2014). A Review of the Accounting Role in Ancient and Colonial Period: A Case Study of Indonesian Telecomunication Industry. Jurnal Akuntansi dan Keuangan Indonesia 3, 1-24.

Budiasih, I. G. A. (2016). Social and Environment Accounting Practices at the Time of the Ancient Bali. Procedia - Social and Behavioral Sciences 219, 145-151. doi: 10.1016/j.sbspro.2016.04.056.

Budiasih, I. G. A. and Sukoharsono (2012). Accounting Practices and The Use of Money in The Reign of King Udayana in Bali: An Ethnoarcheological Approach. The Indonesian Journal of Accounting Research, 15-15.

Budiasih, I. G. A. N. (2012). Construction Of Agriculture Accounting Practices In The Reign Of King Udayana Bali. In The Fourth International Consortium on Accounting (Ethnoarchaeological Approach).

Budiasih, I. G. A. N. (2014). Fenomena Akuntabiliyas Perpajakan Jaman Bali Kuno: Suatu Studi Interpretif. . Jurnal Akuntansi Multiparadigma 5, 409-420.

Burchell, S., Clubb, C., and Hopwood, A. G. (1985). Accounting in its social context: Towards a history of value added in the United Kingdom. doi: 10.1016/ 0361-3682(85)90002-9.

Ezzamel, M. and Willmott, H. (2004). Rethinking strategy: contemporary perspectives and debates. doi: 10.1057/palgrave.emr.1500009. https://dx.doi.org/10. 1057/palgrave.emr.1500009.

Foucoult, M. (1975). Discipline and punish. A. Sheridan, $\operatorname{Tr}$ (Paris, FR, Gallimard).

Hoskin, K. W. and Macve, R. H. (1986). Accounting and the examination: A genealogy of disciplinary power. Accounting, Organizations and Society 11, 105-136. doi: 10.1016/0361-3682(86)90027-9. masa tersebut belum banyak di telaah dan bisa menjadi kesempatan bagi peneliti dengan mempertimbangkan kesediaan data pendukung akuntansi pada masa itu. Sejarah akuntansi juga bisa dituliskan dalam bentuk sejarah kontemporer pada bagaimana perkembangan akuntansi masa kini pada perubahan-perubahan yang terjadi di masa kini. Eksplorasi tersebut belum banyak diteliti dan bisa menjadi topik penelitian yang menarik.

\section{KESIMPULAN}

Dari paparan diatas dapat disimpulkan bahwa perkembangan penelitian sejarah akuntansi dengan menggunakan pendekatan New Accounting History sudah banyak diteliti dan bisa diterima sebagai metoda pembacaan sejarah akuntansi yang mampu memberikan gambaran tentang bagaimana akuntansi berkembang mengikuti perkembangan lingkungan sosial dan ekonomi tempat akuntansi dipraktikan sehingga sejarah akuntansi bisa dipahami secara utuh dan lebih baik lagi.

\section{PENDANAAN}

Penelitian ini menggunakan pendanaan secara mandiri.

\section{UCAPAN TERIMA KASIH}

Peneliti mengucapkan terimakasih kepada pihak UIN Sunan Ampel Surabaya dan Universitas Muhammadiyah Sidoarjo serta pihak-pihak terkait yang sudah membantu penulis menyelesaikan penelitian ini dengan baik.
Lutfillah, N. Q. and and, E. G. S. (2013). Historiografi Akuntansi Indonesia pada Masa Mataram Kuno (Abad VII-XI Masehi). Jurnal Akuntansi Multiparadigma 4, 75-84. doi: 10.18202/jamal.2013.04.7183.

Lutfillah, N. Q., Sukoharsono, E., Mulawarman, A. D., and Prihatiningtias, Y. W. (2016). Revealing the Accounting Existence Through Debt-Receivable Practice at Majapahit Kingdom Era (1350). Accounting and Finance Review (AFR) 1, 5965.

Lutfillah, N. Q. and Sukoharsono, E. G. (2013). Historiografi Akuntansi Indonesia Masa Mataram Kuno (Abad VII-XI Masehi). Jurnal Akuntansi Multiparadigma $4,75-84$.

Lutfillah, Q. (2014). Akuntansi dalam Penetapan Sima Masa Jawa Kuno. Jurnal Akuntansi Multiparadigma 5, 262-272.

Miller (1993). Genealogies of calculation. Accounting, organizations and Society 18, 631-647.

Miller, P. and Leary, T. (1987). Accounting and the construction of the governable person. Accounting, organizations and Society 12, 235-265.

Poster, M. (1982). Foucault and history. Social Research, 116-142.

Rosyinadia, C. D., Sukoharsono, E. G., and Djamhuri, A. (2014). Accounting and Accountability Strategies of Gajah Mada's Government: Analysis of PowerKnowledge. Journal of Economics and Finance 5.

Stewart, R. E. (1992). Pluralizing Our Past: Foucault in Accounting History. Accounting, Auditing \& Accountability Journal 5, 57-73. doi: 10.1108/ 09513579210011862.

Sukoharsono, E. G. (1995). Accounting, Colonial Capitalists, and Liberal Order: The Case of Accounting History in Indonesia during the Dutch Colonial Period of the Mid-to-End of the 19th Century. The International Journal of Accounting 
and Business Society 3, 1-28.

Sukoharsono, E. G. (2000). Bookkeeping to professional accounting: a university power in Indonesia. The International Journal of Accounting and Business Society 8, 58-58.

Sukoharsono, E. G. and Gaffikin, M. J. (1993a). Power and knowledge in accounting: Some analysis and thoughts on social, political, and economic forces in accounting and profession in Indonesia. The International Journal of Accounting and Business Society 8.

Sukoharsono, E. G. and Gaffikin, M. J. (1993b). The genesis of accounting in Indonesia: The Dutch colonialism in the early 17 th century. The International Journal of Accounting and Business Society 1, 4-26.

Widhianningrum, P., Sukoharsono, E. G., and Rosidi, R. (2019). Social accounting and ancient javanese society: the case of Borobudur Temple. doi: 10.26784/issn. 1886-1881.v16i2.356. https://dx.doi.org/10.26784/issn.1886-1881.v16i2.356.

Conflict of Interest Statement: The authors declare that the research was conducted in the absence of any commercial or financial relationships that could be construed as a potential conflict of interest.

Copyright (c) 2020 Nawangsari and Hanun. This is an open-access article distributed under the terms of the Creative Commons Attribution License (CC BY). The use, distribution or reproduction in other forums is permitted, provided the original author(s) and the copyright owner(s) are credited and that the original publication in this journal is cited, in accordance with accepted academic practice. No use, distribution or reproduction is permitted which does not comply with these terms. 


\section{LIST OF TABLES}

1 Perkembangan Sejarah Akuntansi perspektif NAH di Indonesia . . . . . . . . . . . . . . . . . . 
TABLE 1 | Perkembangan Sejarah Akuntansi perspektif NAH di Indonesia

\begin{tabular}{|c|c|c|c|c|c|}
\hline JUDUL & \multicolumn{2}{|c|}{ TAHUNPENERBIT } & PENULIS & FOKUS & $\begin{array}{l}\text { ALAT } \\
\text { ANALI- } \\
\text { SIS }\end{array}$ \\
\hline $\begin{array}{l}\text { The Genesis of Accounting in Indonesia in the early } \\
\text { of } 17 \text { th Century }\end{array}$ & 1993 & $\begin{array}{l}\text { The Indonesian } \\
\text { Journal of } \\
\text { Accounting and } \\
\text { Business Society }\end{array}$ & Dr. Eko G. Sukoharsono & Pencatatan, uang & $\begin{array}{l}\text { Arke- } \\
\text { ologi } \\
\text { Penge- } \\
\text { tahuan }\end{array}$ \\
\hline $\begin{array}{l}\text { Accounting in A Historical Transition: A Shifting } \\
\text { Dominant belief from Hindu to Islamic } \\
\text { Administration in Indonesia }\end{array}$ & 1998 & $\begin{array}{l}\text { Asia Pacific } \\
\text { Interdisciplinary } \\
\text { Research on } \\
\text { Accounting }\end{array}$ & Dr. Eko G. Sukoharsono & $\begin{array}{l}\text { Penulisan, angka, pajak, tanah, } \\
\text { upeti, emas }\end{array}$ & $\begin{array}{l}\text { Power- } \\
\text { knowledge }\end{array}$ \\
\hline $\begin{array}{l}\text { A Review of The Accounting Role in Ancient and } \\
\text { Colonial Period: A Case Study of Indonesian } \\
\text { Telecomunication Industry }\end{array}$ & 2006 & $\begin{array}{l}\text { Jurnal Akuntansi } \\
\text { dan Keuangan } \\
\text { Indonesia }\end{array}$ & Indra Bastian & $\begin{array}{l}\text { Upeti, pembukuan laporan } \\
\text { keuangan, tarif, militer, SDM, } \\
\text { telekomunikasi }\end{array}$ & $\begin{array}{l}\text { Critical } \\
\text { Review }\end{array}$ \\
\hline $\begin{array}{l}\text { Accounting in the Golden Age of Singosari } \\
\text { Kingdom: A Foucauldian Perspective }\end{array}$ & 2008 & $\begin{array}{l}\text { Simposium } \\
\text { Nasional } \\
\text { Akuntansi (SNA) } \\
\text { ke XI Pontianak }\end{array}$ & Dr. Eko G. Sukoharsono & Angka, penulisan, uang & $\begin{array}{l}\text { Power } \\
\text { Knowl- } \\
\text { edge }\end{array}$ \\
\hline $\begin{array}{l}\text { Construction of Agriculture Accounting Practices in } \\
\text { the Reign of King Udayana Bali: } \\
\text { Ethnoarchaeological Approach }\end{array}$ & 2012 & $\begin{array}{l}\text { The Fourth UB } \\
\text { International } \\
\text { Consortium on } \\
\text { Accounting }\end{array}$ & I Gusti Ayu Nyoman Budiasih & Akuntansi pertanian & $\begin{array}{l}\text { Etnoarke- } \\
\text { ologi }\end{array}$ \\
\hline $\begin{array}{l}\text { Accounting Practices and The Use of Money in } \\
\text { The Reign of King Udayana in Bali: An } \\
\text { Ethnoarcheological Approach }\end{array}$ & 2012 & $\begin{array}{l}\text { The Indonesian } \\
\text { Journal of } \\
\text { Accounting } \\
\text { Research }\end{array}$ & I Gusti Ayu Nyoman Budiasih & Uang & $\begin{array}{l}\text { Etnoarke- } \\
\text { ologi }\end{array}$ \\
\hline $\begin{array}{l}\text { Historigrafi Akuntansi Indonesia Masa Mataram } \\
\text { Kuno (Abad VII-XI Masehi) }\end{array}$ & 2013 & $\begin{array}{l}\text { Jurnal Akuntansi } \\
\text { Multiparadigma }\end{array}$ & $\begin{array}{l}\text { Novrida Qudsi Lutfillah dan } \\
\text { Eko Ganis Sukoharsono }\end{array}$ & Perpajakan & $\begin{array}{l}\text { Sosial } \\
\text { Arke- } \\
\text { ologi }\end{array}$ \\
\hline $\begin{array}{l}\text { Fenomena Akuntabilitas Perpajakan Pada Jaman } \\
\text { Bali Kuno: Suatu Studi Interpretif }\end{array}$ & 2014 & $\begin{array}{l}\text { Jurnal Akuntansi } \\
\text { Multiparadigma }\end{array}$ & I Gusti Ayu Nyoman Budiasih & Perpajakan & $\begin{array}{l}\text { Etnoarke- } \\
\text { ologi }\end{array}$ \\
\hline $\begin{array}{l}\text { Accounting and Accountability Strategies of Gajah } \\
\text { Mada's Government: Analysis of } \\
\text { Power-Knowledge }\end{array}$ & 2014 & $\begin{array}{l}\text { IOSR Journal of } \\
\text { Economics and } \\
\text { Finance }\end{array}$ & $\begin{array}{l}\text { Calysta Dessi Rosyinadia, EG } \\
\text { Sukoharsono, A Djamhuri }\end{array}$ & $\begin{array}{l}\text { Perdagangan, perpajakan dan } \\
\text { akuntabilitas Majapahit pada } \\
\text { masa Gajah Mada }\end{array}$ & $\begin{array}{l}\text { Power- } \\
\text { Knowledge }\end{array}$ \\
\hline $\begin{array}{l}\text { Akuntansi dalam Penetapan Sima Masa Jawa } \\
\text { Kuno }\end{array}$ & 2014 & $\begin{array}{l}\text { Jurnal Akuntansi } \\
\text { Multiparadigma }\end{array}$ & Novrida Qudsi Litfillah & Sima & $\begin{array}{l}\text { Arke- } \\
\text { ologi }\end{array}$ \\
\hline $\begin{array}{l}\text { Revealing the Accounting Existence Through } \\
\text { Debt-Receivable Practice at Majapahit Kingdom } \\
\text { Era (1350) }\end{array}$ & 2016 & $\begin{array}{l}\text { Accounting and } \\
\text { Finance Review }\end{array}$ & $\begin{array}{l}\text { Novrida Qudsi Lutfillah, Eko } \\
\text { Ganis Sukoharsono, Aji Dedi } \\
\text { Mulawarman, Yeney Widya } \\
\text { Prihatiningtias }\end{array}$ & Hutang piutang & $\begin{array}{l}\text { His- } \\
\text { tografi }\end{array}$ \\
\hline $\begin{array}{l}\text { Social and Environment Accounting Practices at } \\
\text { the Time of the Ancient Bali }\end{array}$ & 2016 & Elsevier & I Gusti Ayu Nyoman Budiasih & Akuntansi pertanian & $\begin{array}{l}\text { Etnoarke- } \\
\text { ologi }\end{array}$ \\
\hline $\begin{array}{l}\text { Social Accounting and Ancient Javanese Society: } \\
\text { The Case of Borobudur Temple }\end{array}$ & 2019 & $\begin{array}{l}\text { De Computis, } \\
\text { Revista Espanola } \\
\text { de Historia de la } \\
\text { Contabilidad }\end{array}$ & $\begin{array}{l}\text { Purweni Widhianningrum, Eko } \\
\text { Ganis Sukoharsono, Rosidi }\end{array}$ & Perpajakan & $\begin{array}{l}\text { Interpre- } \\
\text { tive }\end{array}$ \\
\hline $\begin{array}{l}\text { Power and knowledge in accounting: Some } \\
\text { analysis and thoughts on social, political, and } \\
\text { economic forces in accounting and profession in } \\
\text { Indonesia }\end{array}$ & 1993 & $\begin{array}{l}\text { University of } \\
\text { Wollonggong } \\
\text { Research Online }\end{array}$ & $\begin{array}{l}\text { Sukoharsono, E. G., \& } \\
\text { Gaffikin, M. J }\end{array}$ & $\begin{array}{l}\text { Kemunculan, keberadaan dan } \\
\text { perkembangn akuntansi di } \\
\text { Indonesia sampai dengan tahun } \\
1950\end{array}$ & $\begin{array}{l}\text { Power- } \\
\text { Knowledge, } \\
\text { His- } \\
\text { tografi }\end{array}$ \\
\hline $\begin{array}{l}\text { The genesis of accounting in Indonesia: The Dutch } \\
\text { colonialism in the early } 17 \text { th century. }\end{array}$ & 1993 & $\begin{array}{l}\text { The International } \\
\text { Journal of } \\
\text { Accounting and } \\
\text { Business Society, }\end{array}$ & $\begin{array}{l}\text { Sukoharsono, E. G., \& } \\
\text { Gaffikin, M. J }\end{array}$ & Pencatatan, uang & $\begin{array}{l}\text { Arke- } \\
\text { ologi } \\
\text { Penge- } \\
\text { tahuan }\end{array}$ \\
\hline $\begin{array}{l}\text { Accounting, Colonial Capitalists, and Liberal Order: } \\
\text { The Case of Accounting History in Indonesia during } \\
\text { the Dutch Colonial Period of the Mid-to-End of the } \\
\text { 19th Century }\end{array}$ & 1995 & $\begin{array}{l}\text { The International } \\
\text { Journal of } \\
\text { Accounting and } \\
\text { Business Society, }\end{array}$ & Sukoharsono, E. G & $\begin{array}{l}\text { Kebijakan keuangan dan modal } \\
\text { pada masa kolonial Belanda }\end{array}$ & $\begin{array}{l}\text { Power- } \\
\text { Knowledge }\end{array}$ \\
\hline $\begin{array}{l}\text { The Boom of Colonial Investment: Dutch Political } \\
\text { Power in the History of Capital in Indonesia }\end{array}$ & 1998 & $\begin{array}{l}\text { The Indonesian } \\
\text { Journal of } \\
\text { Accounting } \\
\text { Research }\end{array}$ & Sukoharsono, E. G & Sejarah permodalan di Indonesia & $\begin{array}{l}\text { Power- } \\
\text { Knowledge }\end{array}$ \\
\hline $\begin{array}{l}\text { Bookkeeping to professional accounting: a } \\
\text { university power in Indonesia. }\end{array}$ & 2000 & $\begin{array}{l}\text { The International } \\
\text { Journal of } \\
\text { Accounting and } \\
\text { Business Society, }\end{array}$ & Sukoharsono, E. G. (2000). & $\begin{array}{l}\text { Hubungan perkembangan } \\
\text { ekonomi Indonesia pasca } \\
\text { kemerdekaan dengan } \\
\text { perkembangan profesi akuntansi }\end{array}$ & $\begin{array}{l}\text { Power- } \\
\text { knowledge }\end{array}$ \\
\hline
\end{tabular}

